\author{
(1) Mehtap Pehlivanlar Küçük, \\ (1) Burcu Öksüz Güngör, \\ (1) Ahmet Oğuzhan Küçük, \\ (D) Olcay Ayçiçek, \\ (D) Atila Türkyılmaz, \\ (1) Funda Öztuna, \\ (1) Yılmaz Bülbül, \\ (D) Tevfik Özlü
}

\section{Pneumothorax and Subcutaneous Emphysema Evaluation in Patients with COVID-19 in the Intensive Care Unit}

\author{
COVID-19 Tanılı Yoğun Bakım Hastalarında \\ Pnömotoraks ve Subkütan Amfizem Olgularının \\ Değerlendirilmesi
}

Received/Geliș Tarihi : 26.03.2021

Accepted/Kabul Tarihi : 19.11.2021

${ }^{\circ}$ Copyright 2021 by Turkish Society of Intensive Care Turkish Journal of Intensive Care published by Galenos Publishing House.

Mehtap Pehlivanlar Küçük

Karadeniz Technical University Faculty of Medicine, Department of Chest Diseases, Division of Intensive Care Medicine, Trabzon, Turkey

Burcu Öksüz Güngör, Atila Türkyılmaz Karadeniz Technical University Faculty of Medicine, Department of Thoracic Surgery, Trabzon, Turkey

Ahmet Oğuzhan Küçük

Karadeniz Technical University Faculty of Medicine, Department of Anesthesiology and Reanimation,

Division of Intensive Care Medicine, Trabzon, Turkey

Olcay Ayçiçek, Funda Öztuna, Yılmaz Bülbül, Tevfik Özlü

Karadeniz Technical University Faculty of Medicine, Department of Chest Diseases, Trabzon, Turkey

Mehtap Pehlivanlar Küçük, PhD, (凶),

Karadeniz Technical University Faculty of Medicine, Department of Chest Diseases, Division of Intensive Care Medicine, Trabzon, Turkey

E-mail : mehtap_phlvnlr@hotmail.com

Phone : : +905052424490

ORCID ID : orcid.org/0000-0003-2247-4074

ABSTRACT Objective: Pneumothorax (PNX) and subcutaneous emphysema (SCE) have increased in importance as a frequently occurring complication. This study aimed to reveal the frequency, timing, and possible risk factors in patients with PNX and SCE who are followed up with coronavirus disease-2019 (COVID-19) diagnosis in our tertiary intensive care unit (ICU).

Materials and Methods: All patients with confirmed COVID-19 who were followed up and treated in our unit between August 8, 2020, and February 20, 2021, in a 16-bed tertiary ICU and who developed PNX and SCE during their hospitalization were included.

Results: PNX and SCE developed in 16 (9.6\%) of 165 patients who were followed up in our ICU due to COVID-19. Of these 16 patients, $3(18.8 \%)$ survived. The median age of patients was 66.5 years (interquartile range: 58.5-75.5). Diabetes mellitus was the most common comorbidity in patients with PNX and SCE. Additionally, 12 (75\%) patients had a smoking history. Of 15 (93.8\%) patients who developed PNX, 4 (25\%) were bilateral, and SCE developed in $9(56.3 \%)$ patients. Twelve (75\%) patients with PNX and SCE were under invasive mechanical ventilation, 3 (18.8\%) under spontaneous breathing, and $1(6.2 \%)$ under non-invasive mechanical ventilation treatment. The number of oxygen support days until the time PNX and SCE developed was 9 (6.25-17) days in the whole group, the median time was 6 days in the survival group and 9 days in the non-survival group. Conclusion: In the COVID-19 pandemic, complications, such as PNX and SCE, are more frequently observed (9.5\%) than in the general intensive care population and the later period of intensive care admission (median 9 days). Smoking is defined as a risk factor in most of these patients; however, increased PNX rates are thought to be related to both COVID-19 pneumonia and parenchymal damage due to cytokine storms.

Keywords: COVID-19, pneumothorax, intensive care unit

ÖZ Amaç: Koronavirüs hastalığı-2019 (COVID-19) ile takipli yoğun bakım hastalarında pnömotoraks (PNX)/deri altı amfizem (SCE) pandeminin ilk zamanlarında yapılan tanımlamaların aksine sık ortaya çıkan bir komplikasyon olarak önemini artırmaktadır. Bu çalışma ile 3. düzey yoğun bakım ünitemizde (YBÜ) COVID-19 tanısı ile takip edilen PNX/SCE olgularının sıklığını, zamanlamasını ve olası risk faktörlerini ortaya koymak hedeflenmiştir.

Gereç ve Yöntem: On altı yataklı 3. düzey YBÜ'de, 28 Ağustos 2020 ve 20 Şubat 2021 arasında ünitemizde takip ve tedavi edilmiş tüm teyitli COVID-19 hastalarından, yatışları sırasında PNX ve SCE gelişen olgular dahil edilmiştir.

Bulgular: Hedef tarih aralı̆ıında YBÜ'de COVID-19 nedeni ile 165 hasta takip edilmiş olup bu hastaların 16'sında $(\% 9,6)$ PNX/SCE gelişmiştir. Bu 16 hastanın 4'ü (\%25) sağ kalmıştır. Hastaların medyan yaşı 66,5 (çeyrekler açıklığ: 58,5-75,5) idi. PNX/SCE gelişen hastalarda en sık komorbidite diabetes mellitus olarak tespit edildi. Hastaların 12'sinin (\%75) sigara kullanım öyküsü mevcuttu. PNX gelişen $15(\% 93,8)$ hastanın 4'ü $(\% 25)$ bilateraldi. SCE ise $9(\% 56,3)$ hastada gelişti. PNX/ SCE saptanan $12(\% 75)$ hasta invazif mekanik ventilasyon tedavisi altındayken, $3(\% 18,8)$ hasta spontan solunumda, $1(\% 6,2)$ hasta non-invazif mekanik ventilasyon tedavisi altındaydı. PNX/SCE geliştiği ana kadar oksijen desteği verilen gün sayısı tüm grupta 9 (6,25-17) gün iken, sağkalan grupta medyan değer 6 gün, ölen grupta 9 gün idi. Oksijen destek gün süresi ölen grupta yüksek olsa da istatistiksel anlamlı fark saptanmadı $(p=0,439)$.

Sonuç: COVID-19 pandemisinde PNX/SCE gibi komplikasyonlar uzun süreli oksijen desteğini takiben genel yoğun bakım popülasyonundan daha sık $(\% 9,5)$ ve yoğun bakım yatışının daha geç döneminde (medyan 9 gün) gözlenmektedir. Bu hastaların çoğunda bir risk faktörü olarak sigara tanımlansa da PNX oranlarındaki bu artışı hem COVID-19 pnömonisi hem de sitokin fırtınasına bağlı oluşan parankimal hasar ile ilgili olduğunu düşünüyoruz.

Anahtar Kelimeler: COVID-19, pnömotoraks, yoğun bakım ünitesi 


\section{Introduction}

The nature of the severe acute respiratory syndrome coronavirus 2 (SARS-CoV-2) virus, which entered our lives as a pandemic agent, is still not clearly known. The virus, which can cause complex and fatal complications, involves many organ systems and often requires intensive care support. Respiratory failure in patients is usually characterized by air bronchograms, bilateral interstitial infiltrates, and multiple lobar and subsegmental consolidations which are seen as ground glass opacities on computed tomography (CT) (1). Coronavirus disease-2019 (COVID-19) has many diagnosed complications such as arrhythmia, cardiogenic shock, renal and hepatic involvement, thromboembolism, and acute respiratory distress syndrome (ARDS) (2-4). Pneumothorax (PNX) and pneumomediastinum are common complications of mechanical ventilation $(5,6)$. While there is a noticeable increase in the frequency of these complications in COVID19 patients, spontaneous PNX/pneumomediastinum cases have also been described without barotrauma (7). One large review reported 18 different COVID-19-related spontaneous PNX cases followed in different centers (8). In our study, we aimed to reveal the frequency, timing, and possible risk factors of PNX and subcutaneous emphysema (SCE) cases followed up with the diagnosis of COVID-19 in our tertiary intensive care unit.

\section{Materials and Methods}

Our study was carried out in Karadeniz Technical University Faculty of Medicine 16-bed tertiary intensive care unit with the approval of the local Ethics Committee of Karadeniz Technical University Faculty of Medicine (protocol no: 2021/62, date: 25.03.2021) and the Ministry of Health. All cases were diagnosed according to the typical radiological image on CT or Real time polymerase chain reaction diagnosis of SARS-CoV-2 infection. All confirmed COVID19 patients who were followed up and treated in our unit between August 28, 2020 and February 20, 2021 and who developed PNX and SCE during their hospitalization were included in the study.

The diagnoses of the patients were made by bedside ultrasonography (USG) and direct anteroposterior chest radiographs taken in the bed.

Patient data were obtained from retrospective intensive care patient registry, data processing automation records, and clinical course. Radiological images of the patients were accessed from the hospital picture archiving and communication system.

In our study, demographic data of the cases, comorbidities, possible risk factors for PNX, clinical, radiological, and laboratory data, applied oxygen support system [high-flow nasal cannula (HFNC), invasive mechanical ventilation (IMV), non-invasive mechanical ventilation (NIMV)], whether prone position was applied, other medical treatments applied for primary disease, and patient outcome information was recorded. HFNC was administered at a flow rate of $60 \mathrm{l} / \mathrm{min}$ in each patient during the initial phase. In the follow-up, the flow rate was decreased according to respiratory effort of the patients. Surgical procedure (chest tube insertion, etc.) applied to the patient due to PNX/SCE was recorded.

\section{Statistical Analysis}

Data were analyzed with IBM SPSS V23 (Chicago, USA). The compliance of the data to normal distribution was examined using the Shapiro-Wilk test. Non-normally distributed data are presented as the median [interquartile range (IQR): 25-75]. Categorical data are presented as frequency and percentage. The study population was divided in to two groups according to outcome (survived and nonsurvived). Kruskal-Wallis test and Mann-Whitney $U$ test were used to compare quantitative data that did not show normal distribution. Chi-square test was used to compare qualitative data. The significance level was taken as $p<0.05$.

\section{Results}

One hundred sixty-five patients were followed in our intensive care unit due to COVID-19, and 16 (9.6\%) of these patients developed PNX/SCE (Figure 1).

Three $(18.8 \%)$ of these 16 patients survived. Analyses were made by grouping the patients according to the mortality outcome. The median age of the patients was 66.5 years (IQR: 58.5-75.5), and 12 of the patients were male and 4 were female. While all of the female patients died, no mortality was observed in $25 \%$ of the male patients. Diabetes mellitus was the most common comorbidity in patients with PNX/SCE, and there was no significant difference in mortality in any of the comorbidities.

Four $(25 \%)$ of the $15(93.8 \%)$ patients who developed PNX were bilateral. SCE developed in 9 (56.3\%) patients. While chest tube drainage system was set up in 11 (68.8\%) patients, $5(31.2 \%)$ patients were followed conservatively without surgical intervention. PNX/SCE was detected in one 
of the cases in the regression period of covid pneumonia and in the others in ARDS.

HFNC was the most commonly used respiratory support treatment method and was applied to 13 (81.3\%) patients. Twelve patients $(75 \%)$ were placed in the prone position. While all 16 patients were receiving low dose methylprednisolone treatment, 5 (31.2\%) patients received pulse methylprednisolone, 11 (68.8\%) patients tocilizumab, 2 $(12.5 \%)$ patients tocilizumab and pulse methylprednisolone together, and 9 (56.3\%) patients received immune plasma treatment. There was no significant difference in mortality in patients who developed PNX/SCE according to these treatments.

Twelve (75\%) patients with PNX/SCE were under IMV treatment, three (18.8\%) patients were under spontaneous breathing, and one patient (6.2\%) was under NIMV treatment (Table 1). The most dominant risk factor in all patients was smoking. While 12 (75\%) of the patients had a smoking history, there was no significant difference in mortality between smoking and non-smoking groups $(p=0.607)$. When the chest tomography at admission was evaluated, there was no dominant risk factor for PNX/SCE, while three patients had traction bronchiectasis.

The duration of smoking was 30 packs/year (IOR: 25$38.75)$ in all patients. While the number of days given oxygen support until the time PNX/SCE developed was 9 (6.25-17) days in the whole group, the median value was 6 days in the survival group and 9 days in the non-survival group. Although the time spent on oxygen support was higher in the non- survival group, no significant difference was found ( $p=0.439)$. There was no significant difference in terms of IMV duration $(p=0.439)$. The duration of stay in the intensive care unit and the duration of hospital stay were significantly shorter in the non-survival group ( $p=0.005, p=0.014$ respectively) (Table 2 ).

\section{Discussion}

Since the beginning of the COVID-19 pandemic, clinicians' experience with the disease and its complications has increased. Intensive care units have become units where COVID-19 patients under severe respiratory distress are closely monitored. PNX/SCE has increased in importance as a frequent complication in intensive care patients, contrary to the definitions made in the early stages of the pandemic. In a study, 94 of 3,430 intensive care patients had iatrogenic PNX; 42 of them were associated with barotrauma, while 52 were associated with the invasive procedure. The cumulative incidence was determined to be $1.4 \%$ (9). Although PNX/ SCE is observed at a very low rate in general intensive care, it was seen at a much higher rate (20-34\%) in intubated patients in the SARS outbreak caused by a coronavirus strain $(10,11)$. Although PNX/SCE was defined in 16 (9.6\%) of 165 intensive care patients in intensive care unit, this frequency was given as 1-2\% in two separate studies conducted in the early stages of the pandemic in China $(12,13)$. In addition, more recent case reports are available in the literature $(7,8,14-17)$.

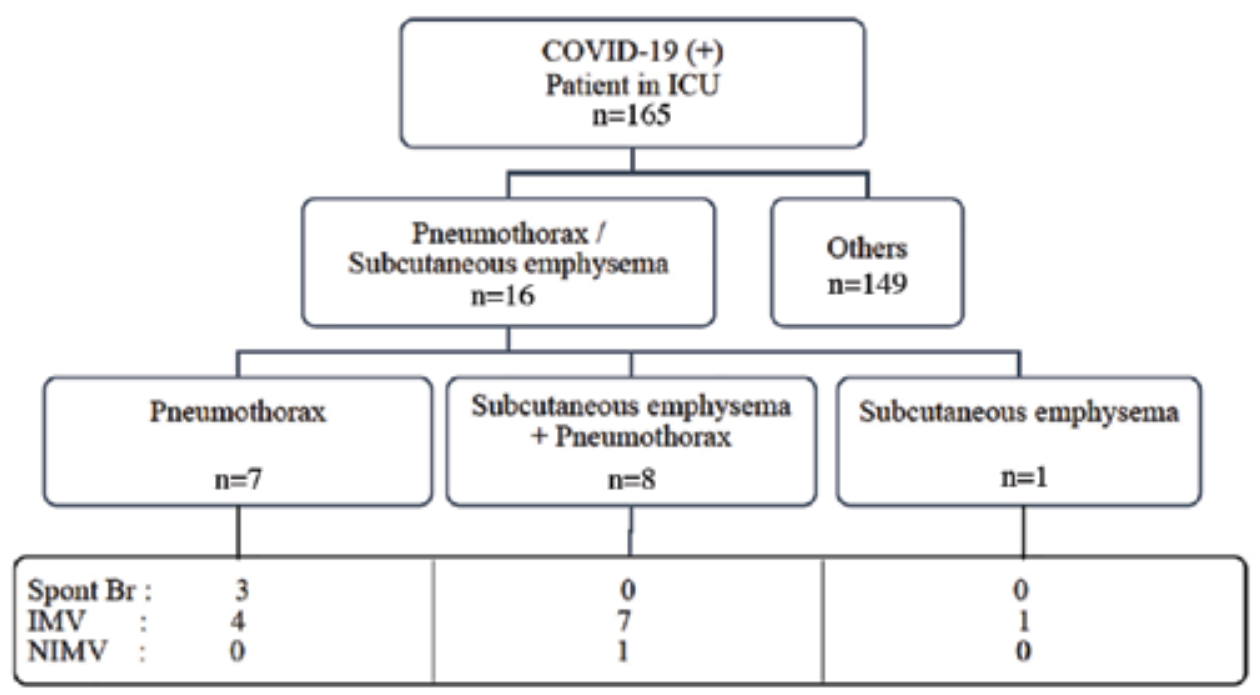

Figure 1. COVID-19 patient diagram

COVID-19: Coronavirus disease-2019, IMV: invasive mechanical ventilation, NIMV: non-invasive mechanical ventilation, ICU: intensive care unit 
Even if PNX is suspected in intensive care units, confirmation of the diagnosis is much more difficult than in clinic patients whose condition is stable. PNX cases, which are mostly diagnosed by direct radiographs taken at the bedside, are also diagnosed by bedside USG in our unit (Figure 2). Lung sliding loss occurs in lung USG and stratosphere sign occurs in $\mathrm{M}$ mode in PNX. Lung sliding and/or B lines exclude the diagnosis of PNX $(18,19)$. Lung USG was performed in all of the presented cases, and the diagnosis was confirmed by direct radiographs at the bedside.

PNX/SCE cases associated with barotrauma, which are among the complications of mechanical ventilation in intensive care units, can be considered as common complications. Therefore, lung protective mechanical ventilation strategies should be adopted. In the recently published Surviving Sepsis Campaign update, it is suggested as "For mechanically ventilated adults with COVID-19 and ARDS, targeting Pplat of $<30 \mathrm{~cm} \mathrm{H}_{2} \mathrm{O}$, they suggest using a higher positive end-expiratory pressure (PEEP) strategy over a lower PEEP strategy in moderate to severe ARDS, If using a higher PEEP strategy (i.e., PEEP $>10 \mathrm{~cm} \mathrm{H}_{2} \mathrm{O}$ ), clinicians should monitor patients for barotrauma." (20). There are also studies where mechanical ventilation does not increase the risk of barotrauma when lung protective mechanical ventilation rules apply $(21,22)$.

\begin{tabular}{|c|c|c|c|c|c|}
\hline & & & Total & Survived & Did not survive \\
\hline & & & $n$ & $n(\%)$ & $n(\%)$ \\
\hline \multirow{5}{*}{ Risk factors } & \multirow{2}{*}{ Smoking } & No & 4 & $1(25)$ & $3(75)$ \\
\hline & & Yes & 12 & $2(16.7)$ & $10(83.3)$ \\
\hline & \multirow{2}{*}{ Chronic lung disease } & No & 13 & $3(23.1)$ & $10(76.9)$ \\
\hline & & Yes & 3 & $0(0)$ & $3(100)$ \\
\hline & Cough attack & No & 16 & $3(18.8)$ & $13(81.3)$ \\
\hline \multirow{6}{*}{ Admission CT findings } & \multirow{2}{*}{ Air cyst } & No & 14 & $3(21.4)$ & $11(78.6)$ \\
\hline & & Yes & 2 & $0(0)$ & $2(100)$ \\
\hline & \multirow{2}{*}{ Bullae } & No & 15 & $3(20)$ & $12(80)$ \\
\hline & & Yes & 1 & $0(0)$ & $1(100)$ \\
\hline & \multirow{2}{*}{ Traction bronchiectasis } & No & 13 & $2(15.4)$ & $11(84.6)$ \\
\hline & & Yes & 3 & $1(33.3)$ & $2(66.7)$ \\
\hline \multirow{6}{*}{ Respiratory support on PNX } & \multirow{2}{*}{ Spontaneous breathing } & No & 13 & $1(7.7)$ & $12(92.3)$ \\
\hline & & Yes & 3 & $2(66.7)$ & $1(33.3)$ \\
\hline & \multirow{2}{*}{ IMV } & No & 4 & $2(50)$ & $2(50)$ \\
\hline & & Yes & 12 & $1(8.3)$ & $11(91.7)$ \\
\hline & \multirow{2}{*}{ NIMV } & No & 15 & $3(20)$ & $12(80)$ \\
\hline & & Yes & 1 & $0(0)$ & $1(100)$ \\
\hline
\end{tabular}

\begin{tabular}{|l|l|l|l|l|}
\hline Table 2. Comparison of outcomes in survived and non-survived groups & Total & $\begin{array}{l}\text { Survived } \\
(\mathbf{n}=13)\end{array}$ & $\begin{array}{l}\text { Non-survived } \\
(\mathbf{n}=3)\end{array}$ & P \\
\hline Duration of smoking, (packs/year) & $30(25-38.75)$ & $30(25-36.25)$ & $35(25-)$ & 0.758 \\
\hline Number of days given oxygen support until the time PNX/SCE developed & $9(6.25-17)$ & $9(7-17)$ & $6(1-)$ & 0.439 \\
\hline Duration of IMV, (days) & $11(4.5-18.5)$ & $10(5-16.5)$ & $19(0-)$ & 0.611 \\
\hline Duration of ICU stay, (days) & $18(11.75-24.75)$ & $16(10.5-21)$ & $25(24-)$ & 0.005 \\
\hline Duration of hospital stay, (days) & $21(17.5-27)$ & $19(14-22.5)$ & $31(27-)$ & 0.014 \\
\hline PNX: Pneumothorax, SCE: subcutaneous emphysema, IMV: invasive mechanical ventilation, ICU: intensive care unit & & \\
\hline
\end{tabular}


However, it is interesting to detect cases of PNX/SCE in COVID-19 pneumonia not only in the case of high-pressure ventilation but also in spontaneously breathing patients. Moreover, no risk factor was found in many of the reported cases $(7,8)$. In three of our patients, PNX developed during spontaneous breathing under oxygen therapy with HFNC. Two of these patients were under the age of 45, without additional risk factors for PNX. One of the two patients developed PNX, which required chest tube drainage while spontaneously breathing on the 19th and the other on the $24^{\text {th }}$ day of oxygen therapy; one of these patients died. In the general intensive care population, barotrauma is seen earlier, and the median time is reported to be 4-5 days after intubation (9).

In our patients, PNX/SCE complications generally developed in the later stages of the disease, on average at 9 (6-17) days of oxygen therapy. Moreover, there were facilitating factors such as air cyst, bullae, and traction bronchiectasis in 6 patients' thoracic CT at the time of admission to the hospital. This timing corresponds to days 11-28, which is defined as the early pulmonary phase/late pulmonary phase of the COVID pneumonic process and its intense oxygen demand (23). In general, known risk factors for the development of primary spontaneous PNX include age between 10 and 30 years, male gender, tall height, and weak body structure. Secondary causes include smoking, chronic obstructive pulmonary disease, infections, alpha-1 antitrypsin deficiency, and trauma $(24,25)$. Not surprisingly, $75 \%$ of our patients were smokers, and most of them (83.3\%) died.

In the COVID-19 pandemic, oxygen support systems have unfortunately had to be used in increasing doses and

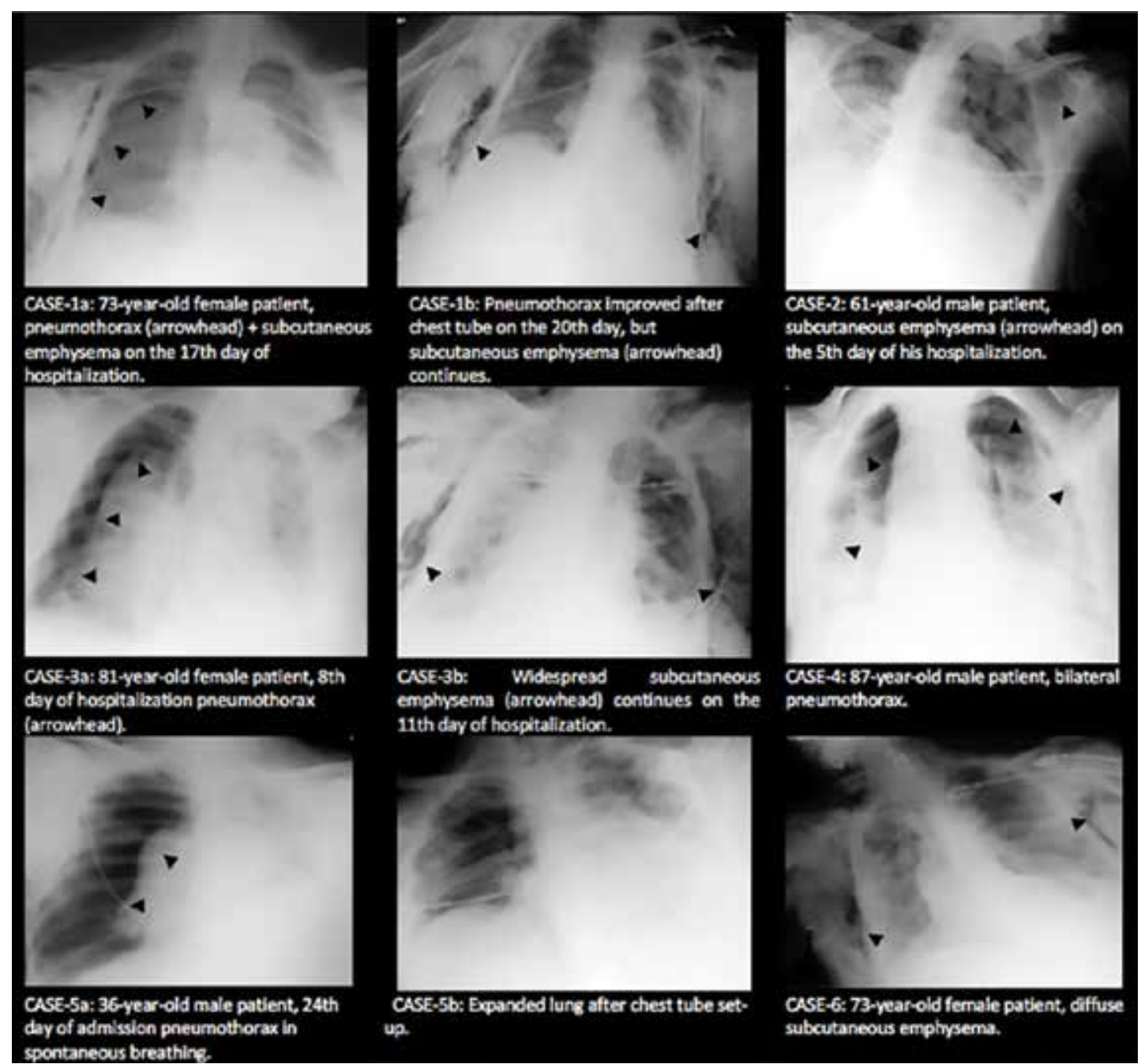

Figure 2. Examples of bedside radiography 
for a long time. When focusing on acute respiratory failure treatment in COVID-19 patients, the long-term effects of intense oxygen exposure can be ignored. Many healthy volunteers experience pleuritic chest pain, cough, substernal heaviness, and shortness of breath within a day of inhaling $100 \%$ oxygen; these symptoms are comonly due to a combination of absorptive atelectasis and tracheobronchitis (26). Most patients treated with a high $\mathrm{FiO}_{2}(>90 \%)$ more than six hours may have edema and bronchoscopic erythema in the large airways, which is thought to reflect hyperoxic bronchitis (27). In addition, regardless of the presence of underlying lung disease the reactive oxygen intermediate concentration in the exhaled gas increases only one hour after inhaling $28 \%$ oxygen (28). Free oxygen radicals also stimulate the harmful inflammatory response caused to secondary tissue damage and/or apoptosis (29). Some of the hypotheses already put forward for the development of PNX/SCE in COVID-19 pneumonia can be listed as follows: oclusion of small airways due to inflammation rises alveolar pressure and causes ruptures with air leaks into the lung interstitium; air travels to the hilum through the bronchovascular sheaths and collects in the mediastinum causing pneumomediastinum; the rupture of the mediastinal parietal pleura causes PNX. In addition, inflammatory cells associated with interleukin-6, which are produced during the cytokine storm associated with SARS-CoV-2, cause bullae formation in the lung by destroying elastic fibers $(30,31)$. On the other hand, edema, vascular occlusion, and microthrombi may contribute to the rupture of pre-existing bullae (26). In our patients, PNX/SCE generally developed in the later stages of the disease and on the ninth day of oxygen therapy, while six patients had facilitating factors such as air cyst, bulla, and traction bronchiectasis on thoracic $\mathrm{CT}$ at the admission to the hospital.

PNX should be suspected in patients even if there are no risk factors such as invasive or non-invasive positive pressure ventilator support, smoking and chronic lung disease, or severe cough. While mild cases can spontaneously resolve with close monitoring, oxygen support, and analgesia, patients with severe respiratory failure, such as our patients, may develop alveolar damage and alveolar rupture more easily and often require chest tube drainage. In these patients, chest tube drainage should be continued until the patients are extubated if they are intubated, and in patients with spontaneous breathing, when the lung is fully expanded and should be continued until 24 hours after the leak has ceased. The limitations of study were; CORADS classification was not used in radiological evaluation and total number of cases is low hence power of study wasn't reached wanted value.

\section{Conclusion}

In intensive care patients who are followed up due to COVID-19 and require high fractionated oxygen, in the case of acute or worsening dyspnea, PNX/SCE should be suspected in these patients with or without mechanical ventilation support. In the COVID-19 pandemic, these complications can be observed more frequently $(9.5 \%)$ than in the general intensive care population and in the later period of intensive care admission (median 9 days). Although smoking is defined as a risk factor in most of these patients, we think that the increase in PNX rates is not only associated with the presence of a certain risk factor or barotrauma, but primarily related to both COVID-19 pneumonia and parenchymal damage caused by cytokine storm. These patients should be closely monitored for these complications in their longterm follow-up.

\section{Ethics}

Ethics Committee Approval: The approval of the local Ethics Committee of Karadeniz Technical University Faculty of Medicine (protocol no: 2021/62, date: 25.03.2021) and the Ministry of Health.

Informed Consent: Retrospective study.

Peer-review: Externally and internally peer-reviewed.

\section{Authorship Contributions}

Surgical and Medical Practices: M.P.K., O.A., A.T., F.Ö., Y.B., T.Ö., Concept: M.P.K., B.Ö.G., A.O.K., O.A., A.T., F.̈., Y.B., T.Ö., Design: M.P.K., A.O.K., O.A., A.T., F.̈., Y.B., T.Ö., Data Collection or Processing: M.P.K., B.Ö.G., A.O.K., Analysis or Interpretation: M.P.K., A.O.K., O.A., Literature Search: M.P.K., B.Ö.G., Writing: M.P.K., A.O.K., B.Ö.G., O.A., A.T., FÖ., Y.B., T.Ö

Conflict of Interest: No conflict of interest was declared by the authors.

Financial Disclosure: The authors declared that this study received no financial support. 


\section{References}

1. Salehi S, Abedi A, Balakrishnan S, Gholamrezanezhad A. Coronavirus Disease 2019 (COVID-19): A Systematic Review of Imaging Findings in 919 Patients. AJR Am J Roentgenol 2020;215:87-93.

2. Wang D, Hu B, Hu C, Zhu F, Liu X, Zhang $J$, et al. Clinical Characteristics of 138 Hospitalized Patients With 2019 Novel Coronavirus-Infected Pneumonia in Wuhan, China. JAMA 2020;323:1061-9.

3. Klok FA, Kruip MJHA, van der Meer NJM, Arbous MS, Gommers DAMPJ, Kant KM, et al. Incidence of thrombotic complications in critically ill ICU patients with COVID-19. Thromb Res 2020;191:145-7.

4. Yang F, Shi S, Zhu J, Shi J, Dai K, Chen $X$. Analysis of 92 deceased patients with COVID-19. J Med Virol 2020;92:2511-5.

5. Yao W, Wang $T$, Jiang B, Gao F, Wang $\mathrm{L}$, Zheng $\mathrm{H}$, et al. Emergency tracheal intubation in 202 patients with COVID19 in Wuhan, China: lessons learnt and international expert recommendations. Br J Anaesth 2020;125:e28-e37.

6. Jacobi A, Chung M, Bernheim A, Eber C. Portable chest X-ray in coronavirus disease-19 (COVID-19): A pictorial review. Vol. 64, Clinical Imaging. Elsevier Inc; 2020. p. 35-42.

7. Elhakim TS, Abdul HS, Pelaez Romero C, Rodriguez-Fuentes Y. Spontaneous pneumomediastinum, pneumothorax and subcutaneous emphysema in COVID-19 pneumonia: a rare case and literature review. BMJ Case Rep 2020;13:e239489.

8. Alhakeem A, Khan MM, Al Soub H, Yousaf Z. Case Report: COVID-19Associated Bilateral Spontaneous Pneumothorax-A Literature Review. Am J Trop Med Hyg 2020;103:1162-5.

9. de Lassence A, Timsit JF, Tafflet M, Azoulay E, Jamali $S$, Vincent $F$, et al. Pneumothorax in the intensive care unit: incidence, risk factors, and outcome. Anesthesiology 2006;104:5-13.

10. Lew TW, Kwek TK, Tai D, Earnest A, Loo S, Singh K, et al. Acute respiratory distress syndrome in critically ill patients with severe acute respiratory syndrome. JAMA 2003;290:374-80.

11. Fowler RA, Lapinsky SE, Hallett D, Detsky AS, Sibbald WJ, Slutsky AS, et al. Critically ill patients with severe acute respiratory syndrome. JAMA 2003;290:367-73

12. Chen N, Zhou M, Dong X, Qu J, Gong F, Han $Y$, et al. Epidemiological and clinical characteristics of 99 cases of 2019 novel coronavirus pneumonia in Wuhan, China: a descriptive study. Lancet 2020;395:507-13

13. Yang $X, Y u Y, X u J$, Shu $H, X i a ~ J$, Liu $H$, et al. Clinical course and outcomes of critically ill patients with SARS-CoV-2 pneumonia in Wuhan, China: a singlecentered, retrospective, observational study. Lancet Respir Med 2020;8:47581.

14. George B, Megally M, Mrejen-Shakin K. Spontaneous pneumothorax and spontaneous pneumomediastinum in non-intubated patients in the setting of Severe Acute Respiratory Syndrome Coronavirus 2. Chest 2020;158:A1653-4.

15. Muhammad Al, Boynton EJ, Naureen S. COVID-19 with bilateral pneumothoraces- case report. Respir Med Case Rep 2020;31:101254.

16. Talan L, Şaşal Solmaz FG, Ercan U, Akdemir Kalkan I, Yenigün BM, Yüksel C, et al. COVID-19 pneumonia and pneumothorax: case series. Tuberk Toraks 2020;68:437-43.

17. Vahapoğlu A, Akpolat B, Çavuş Z, Genç Moralar D, Türkmen A. Spontaneous Hemopneumothorax During the Course of COVID-19 Pneumonia. Turkish J Intensive Care 2020;18:46-9.

18. Lichtenstein D, Mezière G, Biderman $P$, Gepner A. The "lung point": an ultrasound sign specific to pneumothorax. Intensive Care Med 2000;26:1434-40.

19. Lichtenstein DA, Lascols N, Prin S, Mezière G. The "lung pulse": an early ultrasound sign of complete atelectasis. Intensive Care Med 2003;29:2187-92.

20. Alhazzani W, Møller MH, Arabi YM, Loeb M, Gong MN, Fan E, et al. Surviving Sepsis Campaign: guidelines on the management of critically ill adults with Coronavirus Disease 2019 (COVID-19)
Intensive Care Med 2020:46:854-87.

21. Özdemir S, Bilgi DÖ, Köse S, Oya G. Pneumothorax in patients with coronavirus disease 2019 pneumonia with invasive mechanical ventilation. Interact Cardiovasc Thorac Surg 2021;32:351-5

22. Guven BB, Erturk T, Kompe Ö, Ersoy A. Serious complications in COVID19 ARDS cases: pneumothorax, pneumomediastinum, subcutaneous emphysema and haemothorax. Epidemiol Infect 2021;149:e137.

23. EVMS COVID-19 Management protocol An overview of the MATH+ and I-MASK+ Protocols. 2020

24. Gupta D, Hansell A, Nichols T, Duong T, Ayres JG, Strachan D. Epidemiology of pneumothorax in England. Thorax 2000;55:666-71

25. Sahn SA, Heffner JE. Spontaneous pneumothorax. N Engl J Med 2000;342:868-74.

26. Comroe JH, Dripps RD, Dumke PR, Deming M. Oxygen toxicity: The effect of inhalation of high concentrations of oxygen for twenty-four hours on normal men at sea level and at a simulated altitude of 18,000 feet. J Am Med Assoc 1945;128:710-7.

27. Sackner MA, Landa J, Hirsch J, Zapata A. Pulmonary effects of oxygen breathing. A 6-hour study in normal men. Ann Intern Med 1975;82:40-3.

28. Carpagnano GE, Kharitonov SA, FoschinoBarbaro MP, Resta O, Gramiccioni E, Barnes PJ. Supplementary oxygen in healthy subjects and those with COPD increases oxidative stress and airway inflammation. Thorax 2004;59:1016-9.

29. Mantell LL, Lee PJ. Signal transduction pathways in hyperoxia-induced lung cell death. Mol Genet Metab 2000;71:35970.

30. Zhang C, Wu Z, Li JW, Zhao H, Wang GQ. Cytokine release syndrome in severe COVID-19: interleukin-6 receptor antagonist tocilizumab may be the key to reduce mortality. Int J Antimicrob Agents 2020;55:105954.

31. Marini JJ, Gattinoni L. Management of COVID-19 Respiratory Distress. JAMA 2020;323:2329-30. 